САХНО Андрей Анатольевич - доктор экономических наук, профессор, профессор кафедры экономики и предпринимательской деятельности, Винницкий национальный аграрный университет (21008, г. Винница, ул. Солнечная, 3, e-mail: andrijsahno@gmail.com).

ПАВЛЮК Ирина Александровна - аспирантка кафедры экономики и предпринимательской деятельности, Винницкий национальный аграрный университет (21008, г. Винница, ул. Солнечная, 3, e-mail: mk0216@ukr.net).

УДК: 657.338 [658.012:338.242]

DOI: 10.37128/2411-4413-2021-2-4

ІНФОРМАЦИЙНЕ

ЗАБЕЗПЕЧЕННЯ

СТРАТЕГІЧНОГО РОЗВИТКУ АГРАРНИХ ПІДПРИЕМСТВ
ПРАВДЮК Н.Л., доктор економічних наук, професор, завідувач кафедри бухгалтерського обліку, Вінницький національний аграрний університет (м. Вінниця)

Досліджуються інформаційні інструменти забезпечення стратегічного розвитку на прикладі аграрних підприємств. Розкрито методологічні основи змісту базових категорій щзодо управління стратегічним розвитком, виокремлено складові структури його інформаційного забезпечення та визначено, щзо інформачійне забезпечення стратегічного розвитку аграрних підприємств - ие науково обтрунтоване управління прочесом постійного зростання обсягу інформації та знань шляхом традиційних і нових інструментів обробки й аналізу інформачії засобами бухгалтерського обліку, та ї̈ використання в діяльності товаровиробників для одержання конкурентних переваг $i$ формування дієвої аграрної політики. Окреслено роль, здійснено оцінку стану, визначено завдання та виявлено особливості й проблеми розвитку економіки та інформаційного забезпечення аграрних підприємств. Спираючись на інструменти стратегічного характеру, до основних напрямів удосконалення інформаційного забезпечення стратегічного розвитку аграрних підприємств віднесено такі, щзо мають трунтуватися на інтенсифікації інформаційних потоків і глибокій аналітичній обробці усього інформачійного масиву, розбудові внутрішньої інформаційної архітектури й забезпечувати гармонізаџію інформащійно-комунікачійних ланцюгів. До них віднесено: автоматизацію прочеедр накопичення, обробки, модуляції та зберігання документів; упровадження нових інструментів інформаційно-комунікаційних технологій; оптимізацію ритмічності інформаційних потоків; гармонізацію внутрішніх та зовнішніх інформаџійно-комунікаџійних ланц̧югів; впровадження мережевих інструментів інформаційно-комунікаційних взаємодій; усунення дублювання інформації; мінімізацію інформаційного шуму тощуо. Впровадження множини заходів щуодо інформачійного забезпечення стратегічного розвитку аграрних підприємств сприятиме переходу до його нової якості й забезпечить генерування конкурентних переваг, підвищить якість обробки інформацї; стимулюватиме формуванню гнучкої інформачійної архітектури; знизить трудомісткість і вартість інформачійного забезпечення.

Ключові слова: інформаційне забезпечення, інформаційна архітектура, бухгалтерський облік, стратегічний розвиток, інформаційно-комунікаційні технології, фінансування, аграрні підприємства.

Рис.: 4. Табл.: 3. Літ.: 18. 


\title{
INFORMATION SUPPORT FOR STRATEGIC DEVELOPMENT OF AGRARIAN ENTERPRISES
}

\author{
PRAVDIUK Nataliia, \\ Doctor of Economic Sciences, Professor, \\ Head of the Department of Accounting, \\ Vinnytsia National Agrarian University
} (Vinnytsia)

\begin{abstract}
Information tools for ensuring strategic development are investigated on the example of agricultural enterprises. The methodological foundations of the content of basic categories for the management of strategic development are revealed, the components of the structure of its information support are highlighted and it is determined that the information support of the strategic development of agricultural enterprises is scientifically grounded management of the process of constant growth of the volume of information and knowledge through traditional and new tools for processing and analyzing information by means of accounting. ts use in the activities of producers to obtain competitive advantages and the formation of an effective agricultural policy. The role was determined, the state was assessed, the tasks were defined and the features and problems of economic development and information support of agricultural enterprises were identified. Based on strategic tools, the main directions of improving information support for the strategic development of agricultural enterprises include those based on the intensification of information flows and analytical processing of the entire information array, the development of internal information architecture and ensuring the harmonization of information and communication chains. These include: automation of procedures for accumulation, processing, modulation and storage of documents; introduction of new tools of information and communication technologies; optimization of the rhythm of information flows; harmonization of internal and external information and communication chains; introduction of network tools for information and communication interactions; elimination of duplication of information; minimization of information noise, etc. The implementation of measures to provide information support for the strategic development of agricultural enterprises will facilitate the transition to its new quality and ensure the generation of competitive advantages, improve the quality of information processing; stimulates the formation of a flexible information architecture; will reduce the complexity and cost of information support.
\end{abstract}

Keywords: information support, information architecture, accounting, strategic development, information and communication technologies, financing, agricultural enterprises.

Fig.: 4. Tabl.: 3. Ref.: 18.

\section{ИНФОРМАЦИОННОЕ ОБЕСПЕЧЕНИЕ СТРАТЕГИЧЕСКОГО РАЗВИТИЯ АГРАРНЫХ ПРЕДПРИЯТИЙ}

\author{
ПРАВДЮК Н.Л., \\ доктор экономических наук, профессор, \\ заведующая кафедрой бухгалтерского учета, \\ Винницкий национальный аграрный университет
} (2. Винница)

Исследуются информационные инструменты обеспечения стратегического развития на примере аграрных предприятий. Раскрыты методологические основы содержания базовых категорий по управлению стратегическим развитием, выделень 
составляющие структуры его информационного обеспечения $u$ определено, что информачионное обеспечение стратегического развития аграрных предприятий - это научно обоснованное управление процессом постоянного роста объема информации и знаний путем традиционных и новых инструментов обработки и анализа информации средствами бухгалтерского учета, ее использование в деятельности товаропроизводителей для получения конкурентных преимуществ и формирования действенной аграрной политики. Определена роль, осуществлена оченка состояния, определень задачи и выявлень особенности и проблемы развития экономики и информачионного обеспечения аграрных предприятий. Опираясь на инструменты стратегического характера, $\kappa$ основным направлениям совершенствования информационного обеспечения стратегического развития аграрных предприятий отнесены те, что основаны на интенсификации информационных потоков и аналитической обработке всего информационного массива, развитии внутренней информачионной архитектуры $u$ обеспечивающие гармонизацию информационнокоммуникационных цепей. $K$ ним отнесень: автоматизаџия процедур накопления, обработки, модулящии и хранения документов; внедрение новых инструментов информационно-коммуникационных технологий; оптимизация ритмичности информационных потоков; гармонизачия внутренних и внешних информационнокоммуникационных иепей; внедрение сетевых инструментов информационнокоммуникационных взаимодействий; устранение дублирования информации; минимизаџия информачионного шума и т.д. Внедрение мероприятий по информачионному обеспечению стратегического развития аграрных предприятий будет способствовать переходу к его новому качеству и обеспечит генерирования конкурентных преимуществ, повысит качество обработки информации; стимулирует формирование гибкой информационной архитектуры; снизит трудоемкость и стоимость информационного обеспечения.

Ключевые слова: информационное обеспечение, информационная архитектура, бухгалтерский учет, стратегическое развитие, информационно-коммуникационные технологии, финансирование, аграрные предприятия.

Рис.: 4. Табл.: 3. Лит.: 18.

Постановка проблеми. В умовах кризових деформацій та наростання соціально-економічних проблем розвиток аграрних підприємств має здійснюватися за певною стратегією, характеризуватись гнучкістю, мобільністю, адаптивністю, властивістю швидкої перебудови до нових ринкових можливостей і викликів зовнішнього середовища. На передній план виходять методи інформаційно-аналітичного забезпечення управління стратегічного розвитку, зокрема, діджиталізація та використання інформаційних систем, які дозволяють здійснити швидке накопичення та аналіз трендів інформаційних потоків, враховувати їх у діяльності та досягати ефективного менеджменту.

Інформаційне забезпечення стратегічного розвитку аграрних підприємств дає змогу подолати невизначеність ринкового середовища, визначити точки контролю, управляти ними і досягати високої ефективності у всіх сферах формування виробничих і фінансових результатів. Тому необхідне наукове узагальнення стану та удосконалення методичної бази інформаційного забезпечення в умовах випереджувальних викликів практики управління.

Аналіз останніх досліджень і публікацій. Теоретико-методичні засади інформаційного забезпечення стратегічного розвитку аграрних підприємств розглядалися багатьма вітчизняними науковцями, зокрема: В. Бабенком, Р. Бруханським, Л. Вдовенко, О. Гудзь, Н. Гудзенко, В. Жуком, М. Зось-Кіор, 
Г. Калетніком, С. Квашею, Н. Коваль, В. Мазуром, Л. Мармуль, Т. Мулик, П. Саблуком, Н. Юрчук та ін. Зокрема, академік Г. Калетнік із колегами підкреслює значення інформаційного забезпечення для стратегічного розвитку аграрних підприємств, оскільки «не одержана вчасно інформація, або іiі відсутність можуть стати основою краху ... і в процесі аналізу, планування i управління, контролю постійно потрібна інформація» [3, с. 12]; для удосконалення стратегічного управління досліджуються питання інноваційного стійкого розвитку $[14$, с. 89]. В. Боковець, Т. Прутська розкрили сутність, проблеми та напрями удосконалення інформаційного забезпечення управління аграрних підприємств у частині формування та обгрунтування стратегії інноваційного розвитку $[1$, c. 79$]$; А. Правдюк, Т. Прутська, М. Правдюк окреслили інформаційне забезпечення управління підприємницькою діяльністю на засадах інституціоналізму $[7$, с. 5]; вплив інформаційних потреб користувачів на структуру звітності для управління дослідили Н. Гудзенко, Н. Коваль, Т. Плахтій, зазначивши, що «в умовах невизначеного середовища, що постійно змінюється, ефективне функціонування підприємства часто залежить від можливості розробки та впровадження креативних управлінських рішень, що здійснюються на основі інформації» [2, с. 102]; В. Фостолович проаналізувала інформаційно-аналітичну базу в інтегрованій системі управління підприємством [9, с. 179]; Н. Юрчук розкрито проблеми економічного, облікового, контрольного й аналітичного забезпечення управління підприємством [10, с. 53]; Р. Бруханський, О. Фурман дослідили облікове інформаційне забезпечення соціально-економічної стратегії аграрного бізнесу і зазначають, що стабільність діяльності сучасних агропідприємств залежить від повноти, якості та своєчасності розвитку стратегічного обліку та аналітичної інформації, включаючи ділових партнерів, конкурентів, динаміку цін, ринкові тенденції, соціальні умови [12, с. 72].

Ю. Кирилов, В. Грановська, Х. Жосан та I. Доценко вказують, що промислова революція через міжгалузеву інтеграцію та розвиток цифрового сільського господарства стимулює формування симбіотично-комплементарної системи активізації технологічних та управлінських інновацій, а стимулювання розвитку інтеграції наукових розробок та результатів стратегічного управління у виробництво, формування ринку надає конкурентні переваги в довгостроковій перспективі $[15$, с. 1430$]$ тощо.

Таким чином, дослідниками визначено, що інформаційне забезпечення в умовах прискореного поступу цифрового середовища відіграє велику роль у стратегічному розвитку аграрних підприємств, впровадженні новітніх досягнень й організації аграрного виробництва. На перший план виходить проблема співвідношення кількості даних та якості інформації, іiі корисність та затребуваність. Нові виклики в аграрній галузі та інноваційні досягнення в інформаційно-комунікаційній сфері зумовлюють необхідність розробки нових наукових підходів й обгрунтування прикладних заходів щодо інформаційного забезпечення стратегічного розвитку підприємств.

Формулювання цілей статті. Мета дослідження полягає в оцінці стану та виявлення проблем інформаційного забезпечення стратегічного розвитку 
аграрних підприємств, розробці нових наукових підходів і обгрунтуванні удосконалення чинної практики.

Виклад основного матеріалу дослідження. Формування теоретичних основ розкриття сутності інформаційного забезпечення стратегічного розвитку відповідають рівневі економічних відносин у розрізі об'єкта дослідження. Методологічна складова реалізовується з урахуванням досягнень економічної теорії, теорії управління, економічного аналізу, інформаційного забезпечення стану аграрних підприємств шляхом обробки великого масиву даних. Обробка та трансформація великих масивів інформації дістала назву «діджиталізація», що походить від англійського «digitalization» i в перекладі означає «оцифровування», «цифровізація», або ж «приведення в цифрову форму» [6].

Цілі, які обслуговує інформаційне забезпечення за допомогою обробки масиву даних, задаються стратегією, яка за визначенням Г. Калетніка, В. Ціхановської, О. Ціхановської являє собою «вибір правил і прийомів, за допомогою яких досягаються цілі тієї чи іншої системи, елементи стратегії підприємства розрізняють як: систему цілей, пріоритет у розподілі ресурсів, правил здійснення управлінських дій» [3, с. 32]. Як зазначає А. Корюгін, створення системи стратегічного розвитку на підприємстві дозволяє пристосуватись до нестабільних умов зовнішнього середовища [5, с. 206]. Система стратегічного розвитку передбачає об'єднання ресурсів, процесів, організаційної структури й обігу документації.

Проблеми інформаційного забезпечення стратегії, на думку А. Корюгіна, «обумовлені недостатньо розвиненими окремими елементами стратегічного управління» [5, с. 184]. Поліпшення стану інформаційного забезпечення управління Н. Юрчук вбачає у впровадженні інформаційних систем i технологій, які є «обов’ язковою умовою діяльності сучасного підприємства, що сприятиме прийняттю обгрунтованих стратегічних управлінських рішень, спрямованих на зростання конкурентоспроможності і посилення економічної безпеки підприємства $[10$, с. 53]».

Т. Прутська [8, с. 36] підкреслює, що генераторами кризового стану в агроформуваннях є «низка чинників, серед яких - значні скорочення фінансової підтримки аграрних формувань із боку держави, проявлення значного диспаритету цін на засоби виробництва і реалізовану сільським господарством продукцію, значні скорочення кредитів, недосконалість моделей державної підтримки агробізнесу». 3 цього слідує, що орієнтири стратегічного розвитку сільськогосподарських підприємств, у тому числі формування інформаційного забезпечення цього процесу, має визначати держава.

Процес діджиталізації за підтримки державних програм, стратегій та концепцій сталого розвитку дозволяє оптимізувати господарську діяльність. За аналізом суті категорії нами узагальнено, що інформаційне забезпечення стратегічного розвитку аграрних підприємств - це науково обгрунтоване управління процесом постійного зростання обсягу інформації та знань шляхом традиційних і нових інструментів обробки й аналізу інформації засобами бухгалтерського обліку, за допомогою сучасних технологій та їі використання в діяльності товаровиробників для одержання конкурентних переваг i 
формування дієвої аграрної політики.

Щоб адекватно оцінити потреби інформаційного забезпечення стратегічного управління, необхідно сформувати точку відліку, якою $\epsilon$ економічний стан аграрних підприємств. Ресурси, які задіяні на досягнення агросектору, досить нерівномірні.

За даними Державної служби статистики України [18] частка реалізованої продукції у загальноекономічній із 3,87\% у 2012 р. зросла до 5,34\% у 2019 р., за цей же період частка капітальних інвестицій зросла з 6,3\% до 9,48\%, частка галузевого валового внутрішнього продукту - з 8,09\% до 9,70\%. При цьому, за даними Національного банку України [17] на аграрні підприємства припадає $8 \%$ кредитування економічних видів діяльності, майже 75\% господарств мають обмежений доступ до кредитних ресурсів. Структура кредитів аграрних підприємств у 2012 і 2019 роках приведена на рис. 1 .

$2012 \mathrm{p}$.

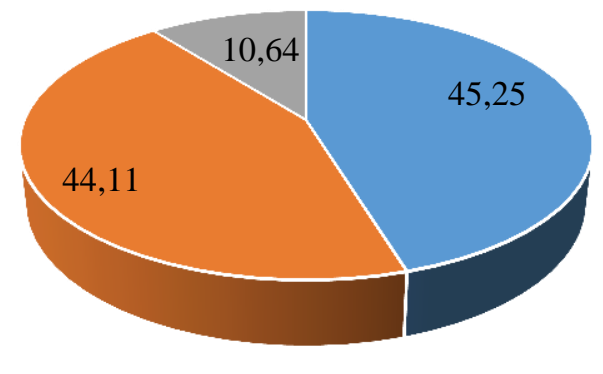

- до 1 року

- більше 5 років
" від 1 року до 5 років

Рuc. 1. Структура кредитів аграрн

Джерело: складено автором за даними [17]

У структурі кредитування з 2012 по 2019 роки частка короткострокових кредитів зросла на 4,87\% з 45,25\% у 2012 р.; середньострокових - знизилась на $11,87 \%$ проти рівня 44,11\% у 2012 р.; частка довгострокових кредитів зросла 3 $10,64 \%$ до $17,64 \%$. Загалом обсяг виданих кредитів досить мізерний, враховуючи потреби аграрних підприємств.

Нестабільність економічного стану аграрних підприємств пояснюється наростанням кризових процесів внутрішнього і зовнішнього характеру. Так, у 2019 p. за даними Державної служби статистики України майже 1/3 підприємств галузі отримали збитки через низьку рентабельність (нижче $5 \%$, особливо у тваринництві.

Причиною є те, що за останні 7 років (2012-2019 рр.) (табл. 1) спостерігається низхідний тренд щодо чисельності поголів'я худоби, за винятком овець і птиці, а зменшення поголів'я спричиняє зниження площ під кормовими культурами, порушуючи традиційні сівозміни. 
Таблиия 1

Динаміка посівних площ та поголів'я худоби і птиці в Україні за 20122019 pp.

\begin{tabular}{|c|c|c|c|c|c|c|c|c|}
\hline \multirow[b]{2}{*}{ Показники } & \multicolumn{7}{|c|}{ Роки } & \multirow{2}{*}{$\begin{array}{c}2019 \mathrm{p} . \\
\text { до } \\
2012 \mathrm{p} . \\
\% \\
\end{array}$} \\
\hline & 2012 & 2013 & 2015 & 2016 & 2017 & 2018 & 2019 & \\
\hline $\begin{array}{l}\text { Культури зернові } \\
\text { зернобобові, тис. га }\end{array}$ & 15449 & 16210 & 14801 & 14739 & 14439 & 14839 & 15279 & 98,98 \\
\hline Культури технічні, тис. га & 7854 & 7869 & 8437 & 8350 & 8656 & 9266 & 9026 & 114,92 \\
\hline $\begin{array}{l}\text { Картопля i овоче-баштанні } \\
\text { культури, тис. га }\end{array}$ & 2023 & 1961 & 1900 & 1823 & 1834 & 1825 & 1820 & 89,97 \\
\hline Культури кормові, тис. га & 2475 & 2289 & 2101 & 1990 & 1936 & 1769 & 1715 & 69,29 \\
\hline $\begin{array}{l}\text { Велика рогата худоба, млн. } \\
\text { гол }\end{array}$ & 4645 & 4534 & 3750 & 3682 & 3941 & 3852 & 3674 & 79,10 \\
\hline у т.ч. корови, млн. гол & 2554 & 2508 & 2166 & 2108 & 2134 & 1998 & 1906 & 74,63 \\
\hline Свині, млн. гол & 7576 & 7922 & 7079 & 6669 & 7141 & 6459 & 6292 & 83,05 \\
\hline Вівці та кози, млн. гол & 1738 & 1735 & 1325 & 1314 & 1456 & 1566 & 1518 & 87,34 \\
\hline Птиця, млн. гол & 214070 & 230290 & 203986 & 201668 & 213206 & 245450 & 254785 & 119,02 \\
\hline
\end{tabular}

Джерело: складено автором за даними [18]

У табл. 2 наведені фінансові тренди аграрних підприємств за період 20122019 pр. за множиною індексів фінансових показників.

Дані табл. 2 свідчать про зростання фінансової залежності на 48\%, за показниками абсолютної ліквідності - на $38 \%$, за показником автономії - на $6 \%$, фінансового ризику - на 3\%. Відбулось зниження показників індексів маневреності капіталу з 0,84 до 0,78, знизилась кредиторська заборгованість на $19 \%$.

Таблиия 2

Основні фінансові тренди аграрних підприсмств України за 2012-2019 рр.

\begin{tabular}{|c|c|c|c|c|c|c|c|}
\hline \multirow{2}{*}{ Індекси } & \multicolumn{6}{|c|}{ Роки } & \multirow{2}{*}{$\begin{array}{l}2019 \text { р. до } \\
2012 \text { р., \% }\end{array}$} \\
\hline & 2012 & 2013 & 2015 & 2016 & 2018 & 2019 & \\
\hline абсолютної ліквідності & 0,097 & 0,087 & 0,049 & 0,018 & 0,052 & 0,061 & 62,89 \\
\hline автономії & 0,535 & 0,501 & 0,401 & 0,240 & 0,491 & 0,503 & 94,02 \\
\hline оперативної ліквідності & 1,876 & 1,723 & 1,503 & 1,192 & 1,564 & 1,645 & 87,69 \\
\hline фінансової залежності & 1,868 & 1,996 & 2,491 & 4,162 & 2,037 & 2,768 & 148,18 \\
\hline маневреності власного капіталу & 0,848 & 0,804 & 0,535 & 0,280 & 0,738 & 0,789 & 93,04 \\
\hline швидкої ліквідності & 1,029 & 0,968 & 1,054 & 1,007 & 0,836 & 0,934 & 90,77 \\
\hline фінансової стабільності & 1,153 & 1,004 & 0,671 & 0,316 & 0,421 & 0,765 & 66,35 \\
\hline покриття & 2,153 & 2,004 & 1,671 & 1,316 & 2,351 & 2,675 & 124,25 \\
\hline кредиторської заборгованості & 0,535 & 0,447 & 0,400 & 0,156 & 0,779 & 0,435 & 81,31 \\
\hline концентрації позикового капіталу & 0,464 & 0,499 & 0,599 & 0,760 & 0,509 & 0,574 & 123,71 \\
\hline $\begin{array}{l}\text { співвідношення } \\
\text { кредиторської заборгованості }\end{array}$ & 0,916 & 0,868 & 1,001 & 0,987 & 0,491 & 0,687 & 75,00 \\
\hline фінансового ризику & 0,867 & 0,996 & 1,491 & 3,162 & 0,866 & 0,895 & 103,23 \\
\hline
\end{tabular}

Джерело: складено автором за даними Державної служби статистики України [18]

М. Ігнатенко та Л. Мармуль визначили, що сільськогосподарські підприємства, які працюють на основі новітніх знань, здатні кардинально змінити свій соціально-економічний стан; сприяють розвитку вертикально орієнтованих ланцюгів вартості, формуванню горизонтальних зв'язків між 
підприємствами. При цьому тяжіння інновацій та впровадження інноваційної діяльності для сільськогосподарських підприємств, у контексті економіки знань та цифрових технологій, постійно зростає. Необхідна передумова активізації введення інновацій сільськогосподарськими підприємствами полягає у визначенні резервів для підвищення ефективності їх роботи [13, с. 32].

За даними анкетування менеджерів аграрних підприємств Вінницької області щодо виявлення їх інформаційних потреб визначено динаміку якості, цінності та ефективності інформаційного забезпечення за 2012-2019 рр. (рис. 2).

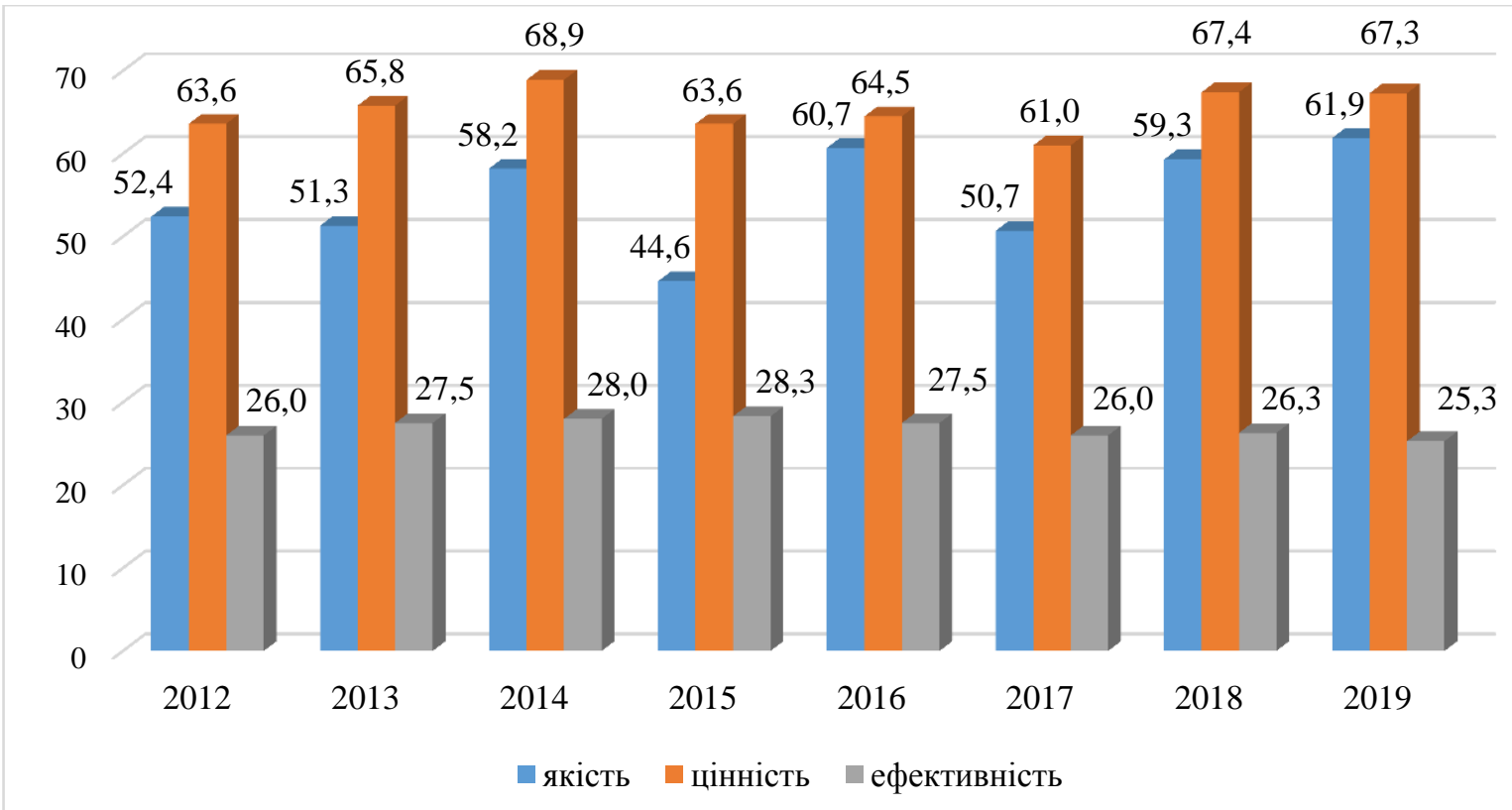

Рuc. 2. Динаміка показників інформаційного забезпечення розвитку аграрних підприємств Вінницької області у 2012-2019 pp., \%

Джерело: сформовано за даними анкетування менеджерів 26 аграрних підприємств Вінницької області

Узагальнені тенденції інформаційного забезпечення свідчать про недостатню ефективність системи управління. Інформація про зовнішне середовище підприємств характеризується відсутністю цілісної структури, чіткої інформації щодо партнерів, постачальників, ринків збуту, стану справ у конкурентів, науково-технічних досягнень, галузевих та територіальних прогнозів, інноваційних рішень, прихильності споживачів до певних видів продуктів і брендів, експортних та імпортних пропозицій тощо. Це зумовлює суб'єктивізм уявлень про середовище ведення бізнесу, ускладнює ухвалення стратегічних планів та заходів. Має місце недостатній рівень управління: у більшості фахівців мало знань та практичних навичок щодо обробки навіть внутрішніх інформаційних потоків та формування стратегій розвитку на їх основі, менеджмент не використовує можливості джерел та обробки інформаційного масиву, у тому числі звітно-облікової інформації.

Виявивши потребу та ніші інформаційного забезпечення стратегічного розвитку, на базовому рівні розглянемо його методичні основи. Концепція стратегічного управління визначає адаптацію ресурсів підприємства до 
майбутніх ситуацій. Орієнтація на вирішення проблем довгострокового зростання та сталого розвитку передбачає використання моделей, методів та інструментів стратегічного управління [5, с. 206]. Формування адекватного інформаційного забезпечення стратегічного розвитку аграрних підприємств тісно переплітається з упровадженням сучасних інформаційно-комунікаційних технологій. До інформаційного забезпечення стратегічного управління належать інформаційні ресурси (інформаційні продукти, інформаційні потоки, Web-content, портали, браузери), інформаційні системи (інформаційні технології, технологічне обладнання), система електронного документообігу (аналітична обробка, CRM, SAP, SAS, електронний архів) та інформаційна архітектура (інформаційний інтерфейс, комунікаційні ланцюги) (рис. 3).

Інформаційне забезпечення стратегічного розвитку аграрних підприсмств
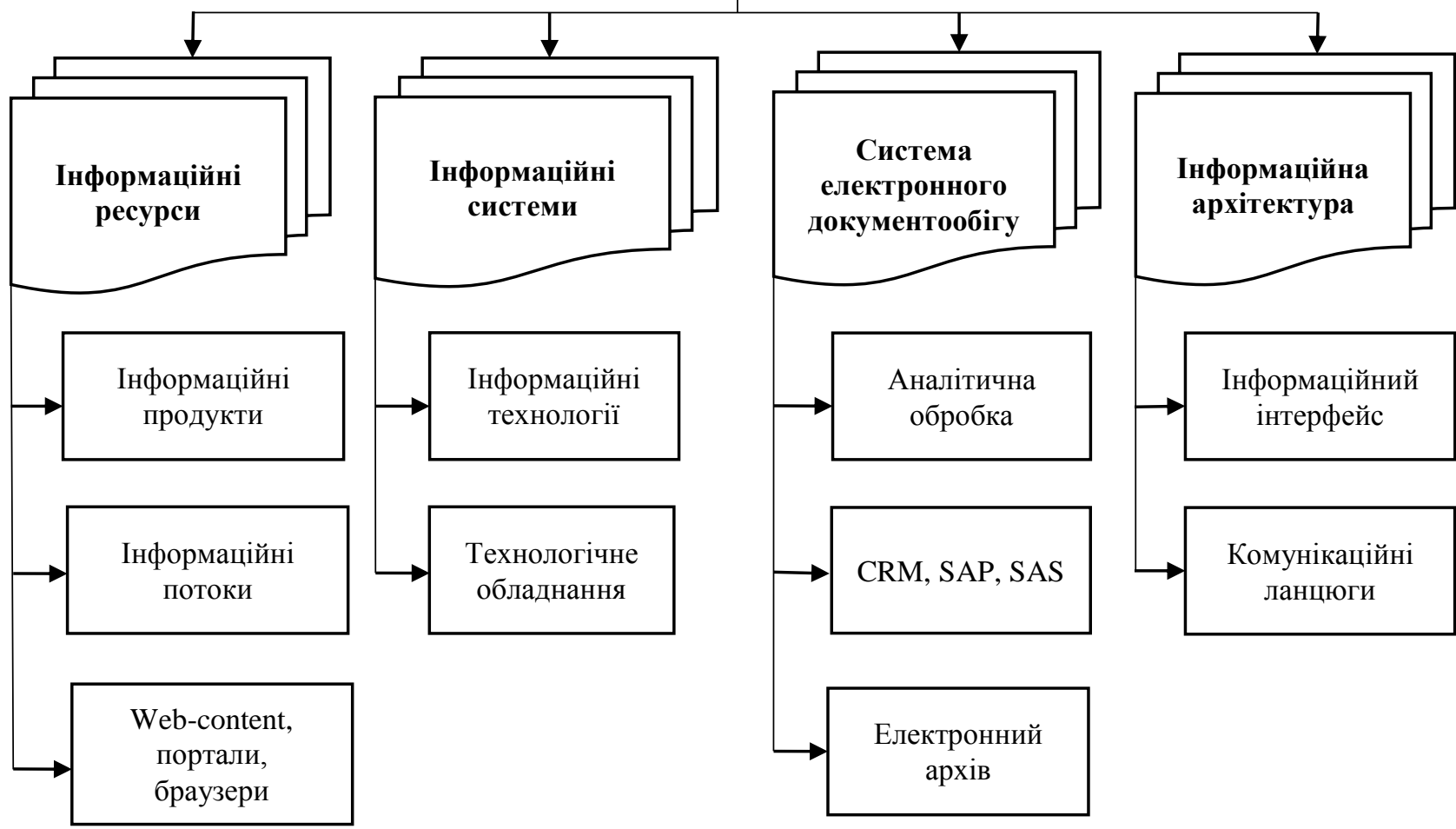

Рис. 3. Інформаційне забезпечення стратегічного розвитку аграрних підприємств

Джерело: систематизовано автором за даними [5; 9; 11$]$

В. Бабенко, О. Накиско, I. Миколенко зазначають, що підходи до використання технологій розвитку сучасних IT-інструментів базуються на програмному впровадженні ISS, виконуються в середовищі Java 3 використанням вебтехнологій Spring MVC. Система включає набір об'єктноорієнтованих програмних модулів та забезпечує транзакції із базою даних $[11$, c. 64].

Виділення стратегічних завдань аграрних підприємств та ролі інформаційного забезпечення у їх реалізації наведено у табл. 3. 


\section{Завдання та напрями інформаційного забезпечення стратегічного розвитку аграрних підприсмств}

\begin{tabular}{|c|c|}
\hline Завдання стратегічного розвитку & Напрями інформаційного забезпечення \\
\hline $\begin{array}{l}\text { - підвищення економічної та фінансової міцності } \\
\text { підприємства; } \\
\text { - широкий провайдинг інновацій; } \\
\text { - виробництво високоякісної сільськогосподарської } \\
\text { продукції із урахуванням нових викликів та } \\
\text { платоспроможності і вимог споживачів; } \\
\text { - розширення інвестиційних можливостей; } \\
\text { - нарощення експорту сільськогосподарської } \\
\text { продукції; } \\
\text { - впровадження стандартів виробництва та якості } \\
\text { сільськогосподарської продукції; } \\
\text { - модернізація матеріальної бази та виробничих } \\
\text { потужностей; } \\
\text { - генерування додаткових конкурентних переваг; } \\
\text { - забезпечення економічної безпеки; } \\
\text { - діджиталізація управління та бізнес-процесів } \\
\text { тощо. }\end{array}$ & 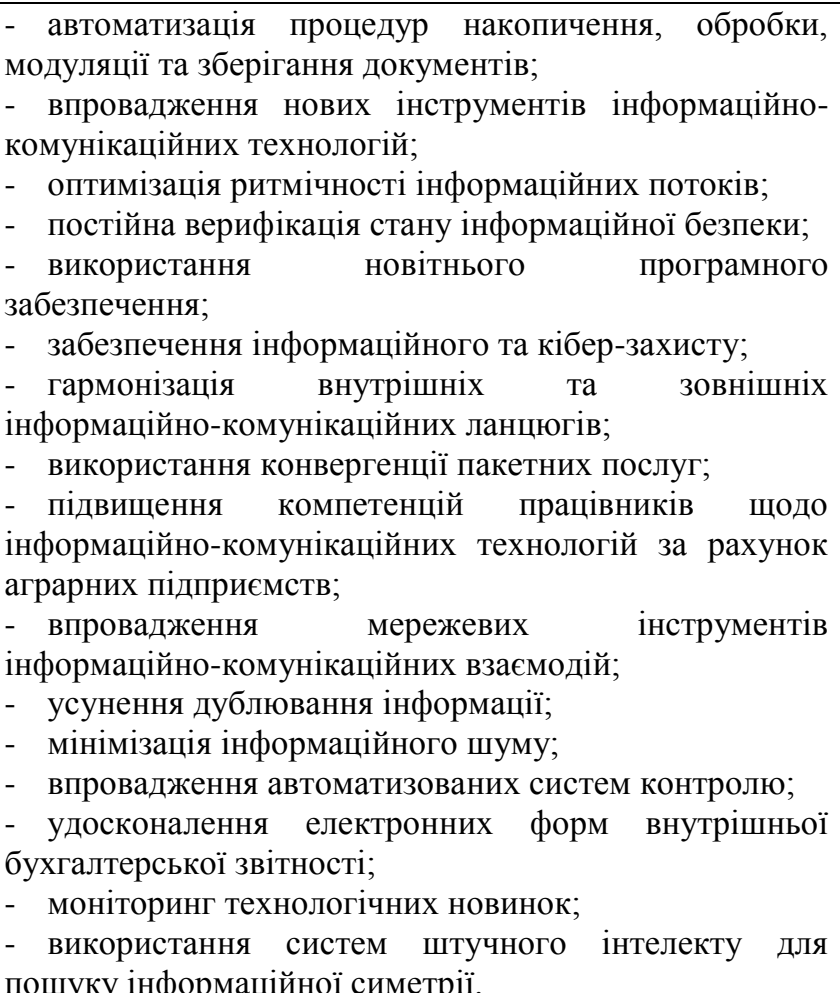 \\
\hline
\end{tabular}

Джерело: систематизовано автором за даними [5, с. 184-206]

Опираючись на завдання стратегічного розвитку аграрних підприємств, до основних напрямів інформаційного забезпечення віднесено заходи, що мають грунтуватися на інтенсифікації інформаційних потоків й глибокій аналітичній обробці усього інформаційного масиву, розбудові внутрішньої інформаційної архітектури й забезпечувати гармонізацію інформаційнокомунікаційних ланцюгів. Головним результатом реалізації стратегічного розвитку аграрних підприємств має стати їх більш високий економічний i технологічний рівень, базований на визначенні впливу основних чинників дієвості інформаційного забезпечення (рис. 4).

За нашими дослідженнями у Вінницькій області найбільш суттєвий вплив має інформаційна архітектура, яка забезпечує повноту інформації на 75\%, далі по спадній тенденції йдуть: комп'ютерні технології - 62\%, інформаційна безпека $-54 \%$, інформаційна симетрія - 51\%, якість програмного забезпечення - 47\%, комунікаційні ланцюги - 41\% тощо. Встановлено, що інформаційне забезпечення стратегічного розвитку аграрних підприємств має характеризуватись гнучкістю, мобільністю, адаптивністю й об'єктивністю, щоб вони могли вчасно реагувати на зміну зовнішнього й внутрішнього середовища та мали можливість здійснити швидкі й комплексні перетворення власних бізнес-процесів. 


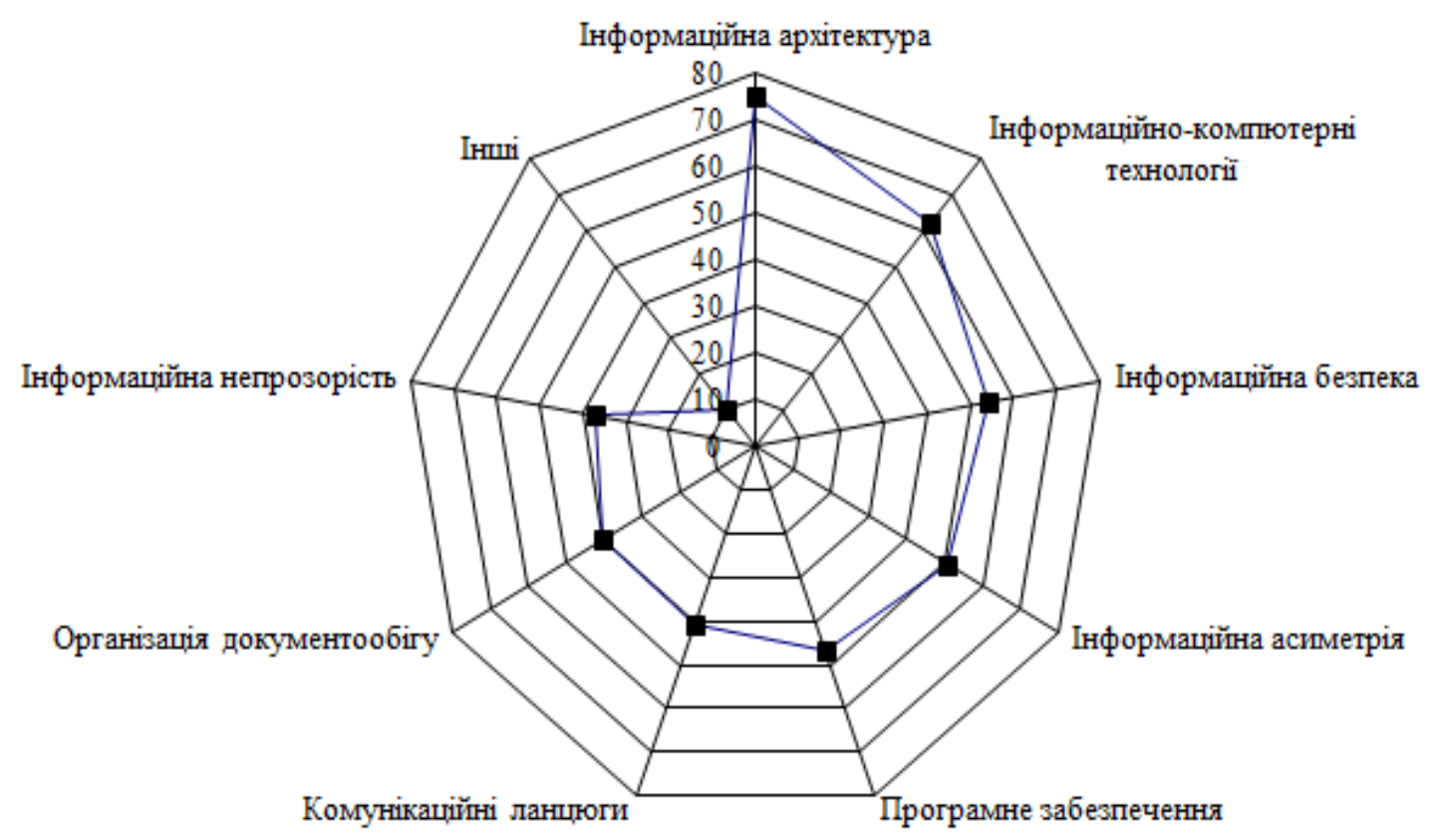

Рис. 4. Вплив основних чинників на дієвість інформаційного забезпечення стратегічного розвитку аграрних підприсмств, \%

Джерело: сформовано на основі анкетування менеджерів аграрних підприємств Вінницької області

Застосування інформаційного забезпечення стратегічного розвитку аграрних підприємств, адаптованого до наявного рівня менеджменту, дозволить генерувати такі переваги: сприятиме мінімізації паперової складової документообігу; підвищить результативність, швидкість та якість обробки інформаційних потоків; сприятиме гармонізації інформаційних потоків i комунікаційних взаємодій; стимулюватиме формуванню гнучкої інформаційної архітектури; знизить трудомісткість і вартість інформаційного забезпечення; сприятиме нарощенню компетентностей персоналу [16, с. 183]; скоротить терміни обробки інформаційних потоків; забезпечить швидкий доступ до інформації; підвищить ризикозахищеність; забезпечить надійність зберігання інформації; забезпечить необхідну конфіденційність обробки та зберігання тощо. Роль інформаційного забезпечення полягає не тільки в підвищенні результативності та інформаційній підтримці стратегічного розвитку, але і в розширенні нових можливостей та примноженні конкурентних переваг аграрних підприємств.

Висновки. Проведене дослідження дало змогу окреслити роль, здійснити оцінку стану, визначити завдання та виявити особливості й проблеми інформаційного забезпечення стратегічного розвитку аграрних підприємств.

Методологічні основи інформаційного забезпечення вимагають уточнення змісту базових категорій щодо управління стратегічним розвитком. Нами визначено, що це науково обгрунтоване управління процесом постійного зростання обсягу інформації та знань шляхом традиційних і нових інструментів обробки й аналізу інформації засобами бухгалтерського обліку, за допомогою IT та ii використання в діяльності товаровиробників для одержання 
конкурентних переваг і формування дієвої аграрної політики.

Оцінку стану інформаційного забезпечення проведено за статистичними та анкетними даними. Розкрито динаміку показників інформаційного забезпечення розвитку аграрних підприємств за критеріями якість-цінністьефективність. Практика аграрного менеджменту свідчить, що інформація про зовнішнє середовище підприємств формується несистемно, відсутня база даних щодо внутрішнього і зовнішнього середовища.

Опираючись на інструменти стратегічного характеру, розроблено наукові підходи й обгрунтовано заходи щодо удосконалення інформаційного забезпечення аграрних підприємств у частині кореляції завдань стратегічного розвитку та відповідних напрямів їх інформаційного забезпечення.

Визначено шляхи удосконалення інформаційного забезпечення стратегічного розвитку: впровадження нових інструментів інформаційнокомунікаційних технологій; гармонізацію внутрішніх та зовнішніх інформаційних ланцюгів; впровадження мережевих інструментів інформаційних взаємодій тощо.

Проблемами подальших наукових розробок $є$ необхідність досліджень щодо орієнтування інформації, сформованої системою бухгалтерського обліку, на врахування потреб стейкхолдерів; посилення практичності обліку, підвищення аналітичності звітності для прийняття стратегічних рішень аграрними підприємствами.

\section{Список використаних джерел}

1. Боковець В.В., Прутська Т.Ю. Формування та обгрунтування стратегії інноваційного розвитку корпоративних підприємств. Інфраструктура ринку. 2017. № 6. С. 79-84.

2. Гудзенко Н.М., Коваль Н.I., Плахтій Т.Ф. Вплив інформаційних потреб користувачів на структуру та наповнення фінансової звітності. Економіка, фінанси, менеджмент: актуальні питання науки і практики. 2018. № 5. C. 102-113.

3. Калетнік Г.М., Ціхановська В.М., Ціхановська О.М. Менеджмент та маркетинг: навч. посібн. Київ: «Хай-Тек Прес», 2011. 580 с.

4. Калетнік Г.М., Козяр Н.О. Стратегічні підходи до інвестування аграрного сектору України в сучасних умовах розвитку АПК. Економіка АПК. 2020. № 12. C. 81-89.

5. Корюгін А.В. Особливості управління стратегічним розвитком підприємства. Університетські наукові записки. 2017. № 4. С. 184-206.

6. Половинкіна А.О., Солнцев С.О. Модель діджиталізації панельних досліджень. Актуальні проблеми економіки та управління: Збірник наукових праць молодих вчених факультету менеджменту та маркетингу КПI імені Ігоря Сікорського. 2020. Вип. 14. URL: http://ape.fmm.kpi.ua/issue/view/10682 (дата звернення 30.04.2021).

7. Правдюк А.Л., Прутська Т.Ю., Правдюк М.В. Інформаційне забезпечення управління підприємницькою діяльністю на засадах інституціоналізму: монографія. Київ: Центр учбової літератури, 2019. 360 с. 
8. Прутська Т.Ю. Пріоритетні напрями розбудови інфраструктури підтримки підприємництва в аграрній сфері та ефективного землекористування. Економіка, фінанси, менеджмент: актуальні питання науки і практики. 2016. № 12. C. 36-45.

9. Фостолович В.А. Інформаційно-аналітична база в інтегрованій системі управління підприємством. Проблеми економічного, облікового, контрольного $i$ аналітичного забезпечення управління підприємством: матеріали II Всеукраїнської науково-практичної конференції молодих учених, 8 грудня 2016 року. Вінниця: «Едельвейс і К». 2016. С. 179-181.

10. Юрчук Н.П. Інформаційні системи в управлінні діяльністю підприємства. Агросвіт. 2015. № 19. С. 53-58.

11. Babenko V., Nakisko O., Mykolenko I. Research of the aspects of modeling of the project management of risk of implementation system information support. Technology audit and production reserves. 2018. № 1 (4). P. 64-69.

12. Brukhanskyi R., Furman O. Accounting information positioning of agrarian business socio-economic strategy. Scientific Bulletin of Polissya. 2017. № 1 (9). P. 72-79.

13. Ihnatenko M., Marmul L. Directions of implementation of innovations in agrarian enterprises of Ukraine. Vectors of competitive development of socioeconomic systems. 2020. Vol. 5 (31). P. 32-35.

14. Kaletnik G., Lutkovska S. Innovative Environmental Strategy for Sustainable Development. European Journal of Sustainable Developmen. 2020. Vol. 9. P. 89-98.

15. Kyrylov Y., Hranovska V., Zhosan H., Dotsenko I. Innovative Development of Agrarian Enterprises of Ukraine in the Context of the Fourth Industrial Revolution. Solid State Technology. 2020. № 63, Issue 6. P. 1430-1448.

16. Pravdiuk N., Pokynchereda V., Pravdiuk M. The human capital of an enterprise: theory and assessment methodology. Baltic Journal of Economic Studies. 2019. Vol. 5. № 2. P. 176-183.

17. Офіційний сайт Національного банку України. URL: НБУ https://bank.gov.ua (дата звернення 30.04.2021).

18. Офіційний сайт Державної служби статистики України. URL: http://www.ukrstat.gov.ua (дата звернення 30.04.2021).

\section{References}

1. Bokovecz, V.V., \& Prutska, T.Yu. (2017). Formuvannya ta obgruntuvannya strategiyi innovacijnogo rozvytku korporatyvnyx pidpryyemstv [Formation and substantiation of the strategy of innovative development of corporate enterprises]. Infrastruktura rynku - Market infrastructure, 6, 79-84 [in Ukrainian].

2. Gudzenko, N.M., Koval, N.I., Plaxtij, T.F. (2018). Vplyv informacijnyx potreb korystuvachiv na strukturu ta napovnennya finansovoyi zvitnosti [The impact of information needs of users on the structure and content of financial statements]. Ekonomika, Finansy, Menedzhment: aktualni pytannya nauky i praktyky - Economy, Finances, Management: current issues of science and practice, 5, 102-113 [in Ukrainian]. 
3. Kaletnik, G.M. Cixanovska, V.M. \& Cixanovska, O.M. (2011). Menedzhment ta marketyng [Management and marketing]. Kyiv: «Xaj-Tek Pres» [in Ukrainian].

4. Kaletnik, G.M., Kolesov, O.S., \& Nedbalyuk, O.O. (2013). Operacijnyj menedzhment [Operational Management]. Kyiv: «Xaj-Tek Pres» [in Ukrainian].

5. Koriuhin, A.V. (2017). Osoblyvosti upravlinnia stratehichnym rozvytkom pidpryiemstva [Features of management of strategic development of the enterprise]. Universytetski naukovi zapysky - University scientific notes, 4, 184-206 [in Ukrainian].

6. Polovynkina, A.O., \& Solntsev S.O. (2020). Model didzhytalizatsii panelnykh doslidzhen [Model of digitalization of panel doslidzhen]. Aktualni problemy ekonomiky i upravlinnia - Actual problems of economy and management, 14. Retrieved from: http://ape.fmm.kpi.ua/issue/view/10682 [in Ukrainian].

7. Pravdyuk, A.L., Prutska, T.Yu., \& Pravdyuk, M.V. (2019). Informatsiine zabezpechennia upravlinnia pidpryiemnytskoiu diialnistiu na zasadakh instytutsionalizmu [Information support for the management of entrepreneurial activity on the basis of institutionalism]. Kyiv: Tsentr uchbovoi literatury [in Ukrainian].

8. Prutska, T.Yu. (2016). Priorytetni napryamy rozbudovy infrastruktury pidtrymky pidpryyemnycztva $\mathrm{v}$ agrarnij sferi ta efektyvnogo zemlekorystuvannya [Priority areas for the development of infrastructure to support entrepreneurship in the agricultural sector and efficient land use]. Ekonomika, Finansy, Menedzhment: aktualni pytannya nauky i praktyky - Economy, Finances, Management: current issues of science and practice, 2, 36-45 [in Ukrainian].

9. Fostolovych, V.A. (2016). Informacijno-analitychna baza $v$ integrovanij systemi upravlinnya pidpryyemstvom [Information and analytical base in the integrated enterprise management system]. Problemy ekonomichnogo, oblikovogo, kontrolnogo $i$ analitychnogo zabezpechennya upravlinnya pidpryyemstvom: materialy II Vseukr. nauk.-praktych. konf. molod. Uchenyx. Vinnytsia: «Edelvejs i K» [in Ukrainian].

10. Yurchuk, N.P. (2015). Informatsiyni systemy $\mathrm{v}$ upravlinni diyalnistyu pidpryyemstva [Information systems in the management of the enterprise]. AhrosvitAgroworld , 19, 53-58 [in Ukrainian].

11. Babenko, V., Nakisko, O., \& Mykolenko, I. (2018). Research of the aspects of modeling of the project management of risk of implementation system information support. Technology audit and production reserves, 1(4), 64-69 [in English].

12. Brukhanskyi, R., \& Furman, O. (2017). Accounting information positioning of agrarian business socio-economic strategy. Scientific Bulletin of Polissya, 1 (9), $72-79$ [in English].

13. Ihnatenko, M., \& Marmul, L. (2020). Directions of implementation of innovations in agrarian enterprises of Ukraine. Vectors of competitive development of socio-economic systems, 5 (31), 32-35 [in English].

14. Kaletnik, G., \& Lutkovska, S. (2020). Innovative Environmental Strategy for Sustainable Development. European Journal of Sustainable Developmen, 9, 8998 [in English]. 
15. Kyrylov, Y., Hranovska, V., Zhosan, H., \& Dotsenko, I. (2020). Innovative Development of Agrarian Enterprises of Ukraine in the Context of the Fourth Industrial Revolution. Solid State Technology, 63, 6, 1430-1448 [in English].

16. Pravdiuk, N., Pokynchereda, V., \& Pravdiuk, M. (2019). The human capital of an enterprise: theory and assessment methodology. Baltic Journal of Economic Studies, 5, 2, 176-183 [in English].

17. Ofitsiinyi sait Natsionalnoho banku Ukrainy [Official site of the National Bank of Ukraine]. bank.gov.ua. Retrieved from: https:// bank.gov.ua [in Ukrainian].

18. Ofitsiinyi sait Derzhavnoi sluzhby statystyky Ukrainy [Official site of the State Statistics Service of Ukraine]. ukrstat.gov.ua. Retrieved from: http://www. /https://ukrstat.gov.ua [in Ukrainian].

\section{Відомості про автора}

ПРАВДЮК Наталія Леонідівна - доктор економічних наук, професор, завідувач кафедри бухгалтерського обліку, Вінницький національний аграрний університет (21008, м. Вінниця, вул. Сонячна, 3, e-mail: npravduyk@ gmail.com).

PRAVDIUK Nataliia - Doctor of Economic Sciences, Professor, Head of the Department of Accounting, Vinnytsia National Agrarian University (21008, Vinnytsia, 3, Soniachna Str., e-mail: npravduyk@gmail.com).

ПРАВДЮК Наталия Леонидовна - доктор экономических наук, профессор, заведующая кафедры бухгалтерского учета, Винницкий национальный аграрный университет $(21008$, г. Винница, ул. Солнечная, 3, e-mail:npravduyk@gmail.com).

УДК 338.43

DOI: $10.37128 / 2411-4413-2021-2-5$

ДОСЛІДЖЕННЯ

ЕКОНОМІЧНОГО

РОЗВИТКУ

ПІДПРИЕМСТВ

ВІННИЦЬКОї

ОБЛАСТІ У

КОНТЕКСТI

АКТИВІЗАЦІї

ВИРОБНИЧОЇ

ДІЯЛЬНОСТІ
САМБОРСЬКА О.Ю., кандидат економічних наук, доцент кафедри адміністративного менеджменту та альтернативних джерел енерхії

КОЛЕСНИК Т.В., кандидат економічних наук, доцент кафедри адміністративного менеджменту та альтернативних джерел енергї,

ПРОНЬКО Л.М., кандидат економічних наук, доцент кафедри адміністративного менеджменту та альтернативних джерел енергї, декан факультету менеджменту та права, Вінницький національний аграрний університет (м. Вінниця) 